\title{
Genetic Variation and Heritability Estimates for Bunch Yield, Bunch Components and Vegetative Traits in Oil Palm Interspecific Hybrids
}

\author{
Mohd Din Amiruddin ${ }^{1}$, Rajanaidu Nookiah ${ }^{1}$, Jalani Sukaimi ${ }^{1}$ and Zakri Abdul Hamid ${ }^{2}$ \\ 1. Malaysian Palm Oil Board, 6 Persiaran Institusi, Bandar Baru Bangi, 43000 Kajang, Selangor, Malaysia \\ 2. Faculty of Science and Technology, Universiti Kebangsaan Malaysia, 43400 Bandar Baru Bangi, Selangor, Malaysia
}

\begin{abstract}
Progeny testing of oil palm interspecific hybrids was conducted in four trials in Kluang, Ulu Paka, Teluk Intan and Carey Island, Malaysia. The interspecific hybrids $(\mathrm{O} \times \mathrm{P})$ were created according to the North Carolina Model I (NCM I) mating design, using Elaeis oleifera $(\mathrm{O})$ and Elaeis guineensis var. pisifera $(\mathrm{P})$ as the maternal and paternal parents, respectively. Differences among $\mathrm{O}, \mathrm{P}$ and O-within-P were determined by the performance (bunch yield, components and vegetative traits) of the progenies. There were significant differences among $\mathrm{P}$ for fresh fruit bunch (FFB) yield, bunch number (BN) and average bunch weight (ABW) in Kluang, Ulu Paka and Teluk Intan, but not in Carey Island. FFB yield was generally higher on coastal soils (Teluk Intan and Carey Island) than inland soils (Kluang and Ulu Paka). Heritability was calculated based on the intraclass correlation. Heritability estimates for these three yield components were variable, depending on the breeding material and environment in which the materials were tested. Fruit to bunch $(\mathrm{F} / \mathrm{B})$ and oil to bunch $(\mathrm{O} / \mathrm{B})$ of parthenocarpic fruits were important in determining the overall $\mathrm{O} / \mathrm{B}$ of the interspecific hybrids. The $\mathrm{O} \times \mathrm{P}$ hybrids in Kluang showed the lowest height increment with only a mean of $14.0 \mathrm{~cm} / \mathrm{year}$, whereas in Ulu Paka and Teluk Intan, the values were higher at $24.0 \mathrm{~cm} /$ year and $25.0 \mathrm{~cm} /$ year, respectively. The study showed that the FFB yields of oil palm interspecific hybrids performed better in coastal soils than inland soils.
\end{abstract}

Key words: Oil palm, interspecific hybrids, genetic variation, heritability estimates, bunch yield, bunch components, vegetative traits.

\section{Introduction}

The commercial oil palm planted is mainly of Elaeis guineensis var. tenera fruit form, which is the $\mathrm{F}_{1}$ hybrid between palms of dura and pisifera fruit forms [1]. E. guineensis is widely accepted to originate from Africa. Lately, attention is being paid to E. oleifera-the South and Central American species, for some of its potentially useful attributes, such as slower height increment [2-5], higher oil unsaturation $[6,7]$ and resistance to certain diseases [8-10]. E. oleifera hybridizes readily with $E$. guineensis to produce interspecific hybrids $(\mathrm{O} \times \mathrm{P})$, and it has been advocated as a promising source of

\footnotetext{
Corresponding author: Mohd Din Amiruddin, Ph.D., research field: oil palm breeding. E-mail: mohddin@mpob.gov.my.
}

new genetic variation in the oil palm [11, 12].

Interspecific hybridization programmes for the oil palm have been conducted in various research centres in the world. The objective is to introgress the desirable qualities from both $E$. guineensis and $E$. oleifera into their progenies. Socfin-Oil Palm Genetics Laboratory (OPGL), United Plantations Berhad (UPB) and the Malaysian Palm Oil Board (MPOB) have introduced substantial E. oleifera germplasm to Malaysia [13]. Rajanaidu et al. [14] did a genetic analysis on yield, vegetative growth and fatty acid composition of the hybrids. The results showed that the gene (additive, dominant or a combination of both) of controlling yield varied with the type of breeding material and environment where they were tested. Fatty acid composition was found to 
be highly heritable and controlled by dominance effects. For vegetative growth, parameters such as rachis length, leaflet number and leaf area were under the control of additive effects, whereas frond production was conditioned by dominance effects. Mukesh and Tan [15] suggested maternal inheritance of iodine value (IV) among interspecific hybrids and their reciprocal crosses. Romero et al. [16] reported that the main differences among hybrids arose from the origin of the E. oleifera genitors, which exhibited high genetic diversity and marked agronomic differences. He further showed the results of the characterization of different hybrids at the molecular, biochemical, physiological and morpho-agronomic levels and also the response of the hybrids to bud rot.

Interest towards oil palm interspecific hybrids has recently gained momentum among breeders and planters in view of its disease resistance qualities against devastating diseases, such as bud rot [17] caused by Phytophthora palmivora in Latin America. The interspecific hybrids appeared to be the best solution as compared to the commercial tenera in Latin America in view of its tolerance against attack by Phytophthora [18].

In this paper, the performance and genetic analysis for bunch yield, bunch components and vegetative traits of the oil palm interspecific hybrids developed at MPOB and planted at four locations are deliberated.

\section{Materials and Methods}

Interspecific hybrids were created based on the North Carolina Model I (NCM I) mating design [19] involving a total of 236 E. oleifera $(\mathrm{O})$ and $76 \mathrm{E}$. guineensis var. pisifera $(\mathrm{P})$ as maternal and paternal parents, respectively. E. oleifera (collections by Socfin) and $\mathrm{P}$ (from Algemeene Vereniging van Rubberplanters ter Oostkust van Sumatra (AVROS), 27B, 29/36 and Sabah Breeding Programme) used in the programme were obtained from plantings in Serdang, Selangor. $\mathrm{O} \times \mathrm{P}$ progenies derived from the crosses were subsequently planted in equilateral triangle system at $8.4 \mathrm{~m}$ spacing (Table 1) in Kluang, Johor as trial 0.181, in Ulu Paka, Terengganu as trial 0.196, in Teluk Intan, Perak as trial 0.821 and in Carey Island, Selangor as trial 0.828 [20].

Table 1 Four $\mathbf{O} \times \mathbf{P}$ progeny trials based on North Carolina Model 1 (NCM 1) mating design.

\begin{tabular}{|c|c|c|c|c|}
\hline Trial No. & 0.181 & 0.196 & 0.821 & 0.828 \\
\hline Plant date & October 1982 & March 1984 & September 1981 & March 1981 \\
\hline Location & Kluang, Johor & Ulu Paka, Trengganu & Teluk Intan, Perak & Carey Island, Selangor \\
\hline Collaborating agency & MPOB & МРOB & UPB & Golden Hope \\
\hline Soil series & Inland alluvial & Inland alluvial & Coastal clay & Carey series \\
\hline $\begin{array}{l}\text { Annual rainfall } \\
\text { (mm/year) }\end{array}$ & $\begin{array}{l}2,058 \\
(1975-1989)\end{array}$ & $\begin{array}{l}3,052 \\
(1983-1990)\end{array}$ & $\begin{array}{l}1,800 \\
(1969-1988)\end{array}$ & $\begin{array}{l}1,935 \\
(1980-1989)\end{array}$ \\
\hline $\begin{array}{l}\text { Previous history } \\
\text { of area }\end{array}$ & Jungle & Jungle & Jungle & Jungle \\
\hline Mating design & NCM 1 & NCM 1 & NCM 1 & NCM 1 \\
\hline Statistical design & CRD & CRD & CRD & CRD \\
\hline $\begin{array}{l}\text { Planting density } \\
\text { (no. of palm/ha) }\end{array}$ & 148 & 148 & 148 & 136 \\
\hline No. of pisiferas & 22 & 12 & 19 & 24 \\
\hline No. of oleiferas/pisiferas & $2-5$ & $2-5$ & $2-4$ & $2-4$ \\
\hline No. of progenies & 74 & 42 & 48 & 72 \\
\hline $\begin{array}{l}\text { No. of palms/progeny/ } \\
\text { replication }\end{array}$ & 5 & 6 & 5 & 5 \\
\hline No. of replications & 3 & 9 & 2 & 2 \\
\hline Total no. of palms & 1,110 & 2,268 & 480 & 720 \\
\hline
\end{tabular}

CRD: completely randomised design. 
The number of fresh fruit bunches and their individual weights were recorded for every palm in 7-10 days harvesting rounds. Four to five bunches per palm were sent for bunch analysis by the method in Ref. [21] as modified by Rao et al. [22] for standard use in Malaysia. The non-destructive methods in Ref. [23] were used for the measurements of vegetative traits.

Intraclass correlations for pisifera (tm), oleiferas-within-pisifera (tf), oleiferas-within-pisifera + pisifera (tf $+\mathrm{m})$ and their corresponding heritabilities $\left(h^{2} m, h^{2} f, h^{2} f+m\right)$ were estimated from their respective variance components [24]. Broad sense heritability $\left(\mathrm{h}^{2} \mathrm{fs}\right)$ of the full-sib families was twice the intraclass correlation [25].

\section{Results and Discussion}

\subsection{Fresh Fruit Bunch Yield and Its Components}

Kluang and Ulu Paka being in inland areas generally gave lower fresh fruit bunch (FFB) yield at 89.1 $\mathrm{kg} / \mathrm{palm} /$ year and $108.7 \mathrm{~kg} / \mathrm{palm} /$ year, respectively, compared to coastal areas of Teluk Intan and Carey Island at $175.0 \mathrm{~kg} / \mathrm{palm} /$ year and 202.4 $\mathrm{kg} / \mathrm{palm} /$ year, respectively. Bunch number $(\mathrm{BN})$ was about twice in coastal areas than that in inland areas. There do not seem to be any particular trend with regards to average bunch weight (ABW) performance for both soil environments. The result nevertheless showed that $\mathrm{BN}$ was more important in contributing towards the FFB yield compared to ABW (Table 2).

In Kluang, there were significant differences among
$\mathrm{P}$ for FFB, BN and ABW, and among O-within-P for $\mathrm{BN}$ and ABW (Table 3). The heritability estimates based on $\mathrm{P}$ were low for $\mathrm{BN}$ but intermediate for FFB and ABW. The heritability estimates based on $\mathrm{O}$-within-P were intermediate for $\mathrm{BN}$ and $\mathrm{ABW}$ but low for FFB.

At Ulu Paka, significant differences among $\mathrm{P}$ were observed only for FFB and BN, but significant differences among O-within-P were observed for FFB, $\mathrm{BN}$ and ABW (Table 4). Similar as for Kluang, the heritability estimates based on $\mathrm{P}$ were low for FFB, $\mathrm{BN}$ and $\mathrm{ABW}$. The heritability estimates based on O-within-P were low for FFB and BN but intermediate for ABW.

There were significant differences among $P$ for FFB, $\mathrm{BN}$ and $\mathrm{ABW}$, and among O-within-P for $\mathrm{ABW}$ at Teluk Intan (Table 5). The heritability estimate based on $\mathrm{P}$ was low for FFB and BN but intermediate for ABW. The heritability estimates based on O-within-P were intermediate for $\mathrm{FFB}, \mathrm{BN}$ and $\mathrm{ABW}$.

At Carey Island, there were no significant differences among $\mathrm{P}$ as well as O-within-P for FFB, $\mathrm{BN}$ and $\mathrm{ABW}$ (Table 6). However, there was significant pisifera $\times$ replication $(\mathrm{P} \times \mathrm{R})$ interaction for FFB, BN and ABW, which indicates inconsistent performance of $\mathrm{P}$ between the two replicates.

\subsection{Bunch Components}

The fertile fruit components of palms in Kluang, Ulu Paka and Teluk Intan gave mean oil to bunch of $3.5 \%, 3.5 \%$ and $3.2 \%$, respectively. For parthenocarpic

Table 2 Means, ranges and least significant differences of FFB yield and its components of $O \times P$ progenies planted in four locations.

\begin{tabular}{|c|c|c|c|c|c|c|c|c|c|c|c|c|}
\hline \multirow{2}{*}{ Trait } & \multicolumn{3}{|c|}{ Kluang } & \multicolumn{3}{|c|}{ Ulu Paka } & \multicolumn{3}{|c|}{ Teluk Intan } & \multicolumn{3}{|c|}{ Carey Island } \\
\hline & Mean & Range & LSD & Mean & Range & LSD & Mean & Range & LSD & Mean & Range & LSD \\
\hline $\begin{array}{l}\text { FFB } \\
\text { (kg/palm/year) }\end{array}$ & 89.1 & $47.0-126.9$ & 33.1 & 108.7 & $80.2-138.2$ & 19.7 & 175.0 & 120.3-216.5 & 39.4 & 202.4 & 154.7-233.1 & 43.4 \\
\hline $\begin{array}{l}\text { BN } \\
\text { (no./palm/year) }\end{array}$ & 10.7 & 4.3-16.2 & 3.1 & 7.9 & $6.2-10.3$ & 1.4 & 21.1 & $18.4-25.3$ & 4.2 & 21.0 & $17.0-24.6$ & 3.7 \\
\hline $\mathrm{ABW}(\mathrm{kg})$ & 8.1 & 5.6-11.1 & 1.6 & 13.7 & $11.6-15.8$ & 1.2 & 7.8 & $5.6-9.7$ & 1.5 & 9.7 & $8.2-11.5$ & 1.6 \\
\hline
\end{tabular}

LSD: least significant difference, the difference between two progeny means is declared significant at $P<0.01$ if it exceeds the value; FFB: fresh fruit bunch yield; BN: bunch number; ABW: average bunch weight; Numbers of progenies are 72, 42, 48 and 72 for Kluang, Ulu Paka, Teluk Intan and Carey Island, respectively. 

and Vegetative Traits in Oil Palm Interspecific Hybrids

Table 3 Mean squares, variance components and heritability estimates from NCM 1 analysis on yield components (1986-1989) in trial 0.181, Kluang (planted in 1982).

\begin{tabular}{|c|c|c|c|c|}
\hline Source & df & FFB & $\mathrm{BN}$ & ABW \\
\hline Replications (R) & 2 & $66,003.09^{* *}$ & $582.78^{* *}$ & $65.59^{* *}$ \\
\hline Pisiferas (P) & 20 & $10,150.28^{* *}$ & $93.75^{* *}$ & $42.35^{* *}$ \\
\hline Oleiferas/Pisiferas (O/P) & 51 & $3,233.39$ & $37.55^{* *}$ & $11.14^{* *}$ \\
\hline $\mathrm{P} \times \mathrm{R}$ & 40 & $2,485.06$ & 25.87 & 4.57 \\
\hline $\mathrm{O} / \mathrm{P} \times \mathrm{R}$ & 102 & $2,062.66$ & 15.62 & 4.32 \\
\hline Seedlings (W) & 893 & $1,996.63$ & 17.33 & 5.02 \\
\hline Pooled error 1 (WP1) & 995 & $2,003.40$ & 17.15 & 4.95 \\
\hline Pooled error 2 (WP2) & 1,035 & $2,022.01$ & 17.49 & 4.93 \\
\hline 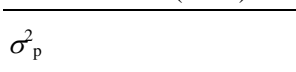 & & $\begin{array}{l}133.55 \\
(5.88)\end{array}$ & $\begin{array}{l}0.94 \\
(4.58)\end{array}$ & $\begin{array}{l}0.64 \\
(10.60)\end{array}$ \\
\hline$\sigma_{\mathrm{o} / \mathrm{p}}^{2}$ & & 76.60 & 1.44 & 0.45 \\
\hline & & (3.37) & (7.02) & $\begin{array}{l}(7.45) \\
0.02\end{array}$ \\
\hline$\sigma_{\mathrm{pr}}^{2}$ & & $\begin{array}{l}26.06 \\
(1.15)\end{array}$ & $\begin{array}{l}0.63 \\
(3.07)\end{array}$ & $\begin{array}{l}0.02 \\
(0.33)\end{array}$ \\
\hline$\sigma_{(o / p) r}^{2}$ & & 12.96 & 0 & 0 \\
\hline$\sigma_{\mathrm{w}}^{2}$ & & - & $\begin{array}{l}\text { (0) } \\
-\end{array}$ & $\begin{array}{l}(0) \\
-\end{array}$ \\
\hline$\sigma_{\text {wp1 }}^{2}$ & & - & - & - \\
\hline$\sigma_{\text {wp2 }}^{2}$ & & $\begin{array}{l}2,022.01 \\
(89.03)\end{array}$ & $\begin{array}{l}17.49 \\
(85.32)\end{array}$ & $\begin{array}{l}4.93 \\
(81.62)\end{array}$ \\
\hline$h_{\mathrm{p}}^{2}$ & & 23.5 & 18.3 & 42.4 \\
\hline$h^{2}{ }_{0}$ & & 13.5 & 28.1 & 29.8 \\
\hline$h_{\mathrm{o}+\mathrm{p}}^{2}$ & & 18.5 & 23.2 & 36.1 \\
\hline
\end{tabular}

df: degrees of freedom for the $F$-ratio on composite items; $\sigma^{2}$ : variance component estimated from the expectation of mean squares; $h^{2}$ : values of heritability based on intra-class correlations; * and ** mean values are significant at $P \leq 0.05$ and $P \leq 0.01$, respectively; -: the most likely estimate value is zero; values in parenthesis are the percentage of phenotypic variance of component; harmonic means for seedlings in female/replication ( $\left.n^{\prime}\right)$ and $\mathrm{O} / \mathrm{P}\left(\mathrm{o}^{\prime}\right)=5.09$ and 3.18, respectively.

Table 4 Mean squares, variance components and heritability estimates from NCM 1 analysis on yield components (1987-1994) in trial 0.196, Ulu Paka (planted 1984).

\begin{tabular}{|c|c|c|c|c|}
\hline Source & $\mathrm{df}$ & FFB & $\mathrm{BN}$ & ABW \\
\hline Replications (R) & 8 & $77,146.17^{* *}$ & $348.08^{* *}$ & $94.59^{* *}$ \\
\hline Pisiferas (P) & 11 & $17,573.18^{*}$ & $56.22^{*}$ & 56.11 \\
\hline Oleiferas/Pisiferas (O/P) & 24 & $7,815.61^{* *}$ & $23.45^{* *}$ & $51.61^{* *}$ \\
\hline $\mathrm{P} \times \mathrm{R}$ & 88 & 1,933.23 & 7.80 & 8.61 \\
\hline $\mathrm{O} / \mathrm{P} \times \mathrm{R}$ & 192 & $2,191.72$ & 9.65 & 7.14 \\
\hline Seedlings (W) & 1,362 & $2,009.50$ & 9.43 & 7.97 \\
\hline Pooled error 1 (WP1) & 1,554 & $2,032.01$ & 9.46 & 7.86 \\
\hline Pooled error 2 (WP2) & 1,642 & $2,026.72$ & 9.37 & 7.91 \\
\hline$\sigma_{\mathrm{p}}^{2}$ & & $\begin{array}{l}87.07 \\
(3.80)\end{array}$ & $\begin{array}{l}0.30 \\
(2.98)\end{array}$ & $\begin{array}{l}0.03 \\
(0.33)\end{array}$ \\
\hline$\sigma_{\mathrm{o} / \mathrm{p}}^{2}$ & & $\begin{array}{l}136.96 \\
(5.98)\end{array}$ & $\begin{array}{l}0.34 \\
(3.38)\end{array}$ & $\begin{array}{l}1.07 \\
(11.73)\end{array}$ \\
\hline & & 0 & 0 & 0.11 \\
\hline$\sigma_{\mathrm{pr}}$ & & $(0)$ & (0) & $(1.21)$ \\
\hline$\sigma_{(o / p) r}^{2}$ & & $\begin{array}{l}39.94 \\
(1.74)\end{array}$ & $\begin{array}{l}0.05 \\
(0.50)\end{array}$ & $\begin{array}{l}0 \\
(0)\end{array}$ \\
\hline$\sigma_{w}^{2}$ & & - & - & - \\
\hline$\sigma_{\text {wp1 }}^{2}$ & & - & - & - \\
\hline$\sigma_{\mathrm{wp} 2}^{2}$ & & $\begin{array}{l}2,026.72 \\
(88.48)\end{array}$ & $\begin{array}{l}9.37 \\
(93.14)\end{array}$ & $\begin{array}{l}7.91 \\
(86.73)\end{array}$ \\
\hline$h_{\mathrm{p}}^{2}$ & & 15.2 & 11.9 & 1.3 \\
\hline$h_{0}^{2}$ & & 23.9 & 13.5 & 46.9 \\
\hline$h_{\mathrm{o}+\mathrm{p}}^{2}$ & & 19.6 & 12.7 & 24.1 \\
\hline
\end{tabular}



and Vegetative Traits in Oil Palm Interspecific Hybrids

Table 5 Mean squares, variance components and heritability estimates from NCM 1 analysis on yield components (1984-1986) from trial 0.821 in Teluk Intan (planted 1981).

\begin{tabular}{|c|c|c|c|c|}
\hline Source & $\mathrm{df}$ & FFB & $\mathrm{BN}$ & ABW \\
\hline Replication (R) & 1 & $55,815.63^{* *}$ & 20.59 & $70.31^{* *}$ \\
\hline Pisiferas (P) & 18 & $10,382.02^{* *}$ & $104.99^{* *}$ & $16.97^{* *}$ \\
\hline Oleiferas/Pisiferas (O/P) & 29 & $2,440.12$ & 35.23 & $4.55^{*}$ \\
\hline $\mathrm{P} \times \mathrm{R}$ & 18 & $1,960.44$ & 29.83 & 3.88 \\
\hline $\mathrm{O} / \mathrm{P} \times \mathrm{R}$ & 29 & $1,452.04$ & 25.77 & 2.29 \\
\hline Seedlings (W) & 379 & $1,887.23$ & 22.37 & 2.65 \\
\hline Pooled error 1 (WP1) & 408 & $1,856.30$ & 22.61 & 2.62 \\
\hline Pooled error 2 (WP2) & 426 & $1,860.70$ & 22.92 & 2.68 \\
\hline$\sigma_{\mathrm{p}}^{2}$ & & $\begin{array}{l}317.07 \\
(13.66)\end{array}$ & $\begin{array}{l}2.80 \\
(10.10)\end{array}$ & $\begin{array}{l}0.46 \\
(13.10)\end{array}$ \\
\hline$\sigma_{\mathrm{o} / \mathrm{p}}^{2}$ & & $\begin{array}{l}100.09 \\
(4.31)\end{array}$ & $\begin{array}{l}0.96 \\
(3.46)\end{array}$ & $\begin{array}{l}0.23 \\
(6.55)\end{array}$ \\
\hline$\sigma^{2}$ & & 43.37 & 0.35 & 0.14 \\
\hline$\sigma_{\mathrm{pr}}$ & & $(1.87)$ & $(1.26)$ & (3.99) \\
\hline$\sigma_{(0 / p) r}^{2}$ & & 0 & 0.69 & 0 \\
\hline$\sigma_{w}^{2}$ & & - & $\begin{array}{l}(2.49) \\
-\end{array}$ & (0) \\
\hline$\sigma_{\text {wp1 }}^{2}$ & & - & - & - \\
\hline$\sigma_{\mathrm{wp2}}^{2}$ & & $\begin{array}{l}1,860.70 \\
(80.16)\end{array}$ & $\begin{array}{l}22.92 \\
(82.68)\end{array}$ & $\begin{array}{l}2.68 \\
(76.35)\end{array}$ \\
\hline$h_{\mathrm{p}}^{2}$ & & 54.6 & 40.4 & 52.4 \\
\hline$h^{2}{ }_{0}$ & & 17.3 & 13.9 & 26.2 \\
\hline$h_{0+p}^{2}$ & & 36.0 & 27.1 & 39.3 \\
\hline
\end{tabular}

df: degrees of freedom for the $F$-ratio on composite items; $\sigma^{2}$ : variance component estimated from the expectation of mean squares; $h^{2}$ : values of heritability based on intra-class correlations; * and ** mean values are significant at $P \leq 0.05$ and $P \leq 0.01$, respectively; -: the most likely estimate value is zero; values in parenthesis are the percentage of phenotypic variance of component; harmonic means for palms in female/rep (n') and $\mathrm{O} / \mathrm{P}\left(\mathrm{o}^{\prime}\right)=4.94$ and 2.38, respectively.

Table 6 Mean squares, variance components and heritability estimates from NCM 1 analysis on yield components (1984-1987) from trial 0.828, Carey Island (planted 1981).

\begin{tabular}{|c|c|c|c|c|}
\hline Source & $\mathrm{df}$ & FFB & $\mathrm{BN}$ & ABW \\
\hline Replication (R) & 1 & 777.58 & 0.01 & 1.96 \\
\hline Pisiferas (P) & 23 & $4,242.14$ & 29.31 & 9.89 \\
\hline Oleiferas/Pisiferas (O/P) & 48 & $2,187.73$ & 19.30 & 4.30 \\
\hline $\mathrm{P} \times \mathrm{R}$ & 23 & $6,162.31^{* *}$ & $32.48^{* *}$ & $12.85^{* *}$ \\
\hline $\mathrm{O} / \mathrm{P} \times \mathrm{R}$ & 48 & $2,974.33$ & 14.87 & 4.10 \\
\hline Seedlings (W) & 522 & $1,992.81$ & 14.87 & 2.68 \\
\hline Pooled error (WP) & 570 & $2,075.46$ & 14.87 & 2.80 \\
\hline$\sigma_{\mathrm{p}}^{2}$ & & $\begin{array}{l}0 \\
(0)\end{array}$ & $\begin{array}{l}0 \\
(0)\end{array}$ & $\begin{array}{l}0 \\
(0)\end{array}$ \\
\hline$\sigma_{\mathrm{o} / \mathrm{p}}^{2}$ & & $\begin{array}{l}0 \\
(0)\end{array}$ & $\begin{array}{l}0.52 \\
(3.09)\end{array}$ & $\begin{array}{l}0.02 \\
(0.52)\end{array}$ \\
\hline & & $\begin{array}{l}\text { (U) } \\
257.77\end{array}$ & $\begin{array}{l}(3.09) \\
1.42\end{array}$ & $\begin{array}{l}(0.52) \\
0.71\end{array}$ \\
\hline$\sigma_{\mathrm{pr}}$ & & (10.06) & $(8.45)$ & (18.39) \\
\hline$\sigma_{(0 / p) r}^{2}$ & & 228.57 & $\begin{array}{l}0 \\
(0)\end{array}$ & 0.33 \\
\hline$\sigma_{w}^{2}$ & & - & (U) & $\begin{array}{l}(0.53) \\
-\end{array}$ \\
\hline$\sigma_{\mathrm{wp}}^{2}$ & & $\begin{array}{l}2,075.46 \\
(81.02)\end{array}$ & $\begin{array}{l}14.87 \\
(88.46)\end{array}$ & 2.80 \\
\hline$h_{\mathrm{p}}^{2}$ & & 0 & 0 & 0 \\
\hline$h^{2}{ }_{0}$ & & 0 & 12.4 & 2.1 \\
\hline$h_{0+\mathrm{p}}^{2}$ & & 0 & 6.2 & 1.0 \\
\hline
\end{tabular}

df: degrees of freedom for the $F$-ratio on composite items; $\sigma^{2}$ : variance component estimated from the expectation of mean squares; $h^{2}$ : values of heritability based on intra-class correlations; * and ** mean values are significant at $P \leq 0.05$ and $P \leq 0.01$, respectively; -: the most likely estimate value is zero; values in parenthesis are the percentage of phenotypic variance of component; harmonic means for seedlings in female/rep (n’) and O/P (o') $=4.29$ and 2.88, respectively. 

and Vegetative Traits in Oil Palm Interspecific Hybrids

fruits, the mean oil to bunch of palms in Kluang, Ulu Paka and Teluk Intan were $7.5 \%, 3.9 \%$ and $1.5 \%$, respectively. The trend of the parthenocarpic fruits in Kluang, Ulu Paka and Teluk Intan corresponded closely to the fruit to bunch (F/B) at $22.1 \%, 14.7 \%$ and $3.9 \%$, respectively. The hybrids generally have low total oil to bunch (TO/B, mean from $4.7 \%$ to $11.0 \%$ ), low mesocarp to fruit (M/F, mean from $63.0 \%$ to $65.7 \%$ ) but high shell to fruit (S/F, mean from $25.8 \%$ to $27.7 \%$ ) (Table 7 ).

In Table 8, it could be found that Kluang showed significant differences among $\mathrm{P}$ and O-within-P for $\mathrm{M} / \mathrm{F}$ and $\mathrm{S} / \mathrm{F}$ of fertile fruits with the heritability estimates being intermediate for both bunch components. However, there were no significant differences among $\mathrm{P}$ and $\mathrm{O}$-within-P for kernel to fruit $(\mathrm{K} / \mathrm{F})$. There were significant differences among $\mathrm{P}$ but not among O-within-P for oil to dry mesocarp (O/DM), oil to wet mesocarp (O/WM) and oil to bunch $(\mathrm{O} / \mathrm{B})$ of fertile fruits. The heritability estimates based on $\mathrm{P}$ were high for $\mathrm{O} / \mathrm{DM}$ and $\mathrm{O} / \mathrm{WM}$ but intermediate for $\mathrm{O} / \mathrm{B}$, whereas heritability estimates based on $\mathrm{O}$-within-P were intermediate for the three components. For parthenocarpic fruits, there were significant differences between $\mathrm{P}$ but not for O-within-P for O/DM, O/WM and O/B. The heritability estimates of parthenocarpic fruits based on $\mathrm{P}$ were intermediate for $\mathrm{O} / \mathrm{DM}, \mathrm{O} / \mathrm{WM}$ and $\mathrm{O} / \mathrm{B}$. Based on O-within-P, the heritability estimates were intermediate for $\mathrm{O} / \mathrm{DM}$ and $\mathrm{O} / \mathrm{WM}$ but low for $\mathrm{O} / \mathrm{B}$ (Table 8).

Ulu Paka had significant differences among $\mathrm{P}$ and O-within-P for M/F, K/F and S/F of fertile fruits. The heritability estimates based on $\mathrm{P}$ were low for $\mathrm{M} / \mathrm{F}$, $\mathrm{K} / \mathrm{F}$ and $\mathrm{S} / \mathrm{F}$ but were intermediate based on O-within-P for all the three components. There were no significant differences among $\mathrm{P}$ and $\mathrm{O}$-within-P for $\mathrm{O} / \mathrm{DM}$ and $\mathrm{O} / \mathrm{B}$. The heritability estimates based on $\mathrm{P}$ were low for $\mathrm{O} / \mathrm{DM}$ and $\mathrm{O} / \mathrm{B}$ but intermediate for $\mathrm{O} / \mathrm{WM}$. Based on O-within-P, the heritability were low

Table 7 Means, ranges and least significant differences of fertile and parthenocarpic bunch components of $O \times P$ progenies planted in three locations.

\begin{tabular}{|c|c|c|c|c|c|c|c|c|c|}
\hline \multirow{2}{*}{ Trait } & \multicolumn{3}{|c|}{ Kluang } & \multicolumn{3}{|c|}{ Ulu Paka } & \multicolumn{3}{|c|}{ Teluk Intan } \\
\hline & Mean & Range & LSD & Mean & Range & LSD & Mean & Range & LSD \\
\hline \multicolumn{10}{|l|}{ Fertile fruits } \\
\hline MFW (g) & 6.8 & 3.3-10.3 & 1.6 & 7.3 & $5.4-9.4$ & 1.1 & 7.5 & 5.8-9.5 & 1.4 \\
\hline MNW (g) & 2.5 & $1.7-4.0$ & 0.8 & 2.9 & $2.0-3.9$ & 0.5 & 3.0 & $1.9-4.2$ & 0.8 \\
\hline M/F (\%) & 65.7 & $42.3-74.0$ & 7.1 & 63.0 & $56.1-70.0$ & 5.0 & 63.4 & 54.6-71.5 & 6.2 \\
\hline K/F (\%) & 8.6 & $6.0-13.0$ & 2.8 & 9.3 & 7.3-12.0 & 2.0 & 9.2 & 6.1-13.0 & 2.3 \\
\hline S/F (\%) & 25.8 & $18.0-44.8$ & 6.2 & 27.7 & $20.5-32.7$ & 4.1 & 27.4 & $22.2-35.9$ & 5.0 \\
\hline O/DM (\%) & 68.4 & $52.0-73.5$ & 4.9 & 66.4 & $62.0-72.8$ & 5.3 & 69.6 & 64.7-74.9 & 4.2 \\
\hline O/WM (\%) & 45.5 & 29.9-52.4 & 7.0 & 39.1 & $32.1-47.4$ & 7.0 & 45.9 & $37.8-50.3$ & 5.5 \\
\hline F/B (\%) & 11.7 & $5.2-21.8$ & 7.5 & 14.6 & $11.0-19.9$ & 5.8 & 11.4 & $3.8-26.8$ & 6.5 \\
\hline O/B (\%) & 3.5 & $1.5-6.9$ & 2.4 & 3.5 & $2.2-4.8$ & 1.5 & 3.2 & $1.3-6.0$ & 1.9 \\
\hline K/B (\%) & 1.0 & $0.5-2.5$ & 0.8 & 1.4 & $0.9-1.9$ & 0.7 & 1.1 & 0.3-3.5 & 0.8 \\
\hline \multicolumn{10}{|c|}{ Parthenocarpic fruits } \\
\hline MFW (g) & 1.8 & $1.0-3.6$ & 1.0 & 2.9 & $1.6-4.7$ & 1.5 & 2.5 & $1.8-3.4$ & 0.7 \\
\hline O/DM (\%) & 66.3 & $51.0-73.2$ & 2.9 & 61.5 & $52.7-68.7$ & 8.0 & 67.2 & $55.6-72.8$ & 7.0 \\
\hline O/WM (\%) & 32.8 & $20.5-42.3$ & 4.0 & 28.2 & 20.5-39.8 & 7.7 & 37.5 & $21.9-46.7$ & 8.5 \\
\hline F/B (\%) & 22.1 & 12.6-30.5 & 4.4 & 14.7 & $11.0-19.9$ & 5.8 & 3.9 & $2.4-5.4$ & 0.7 \\
\hline O/B (\%) & 7.5 & $2.8-11.8$ & 1.4 & 3.9 & $2.8-5.8$ & 1.7 & 1.5 & $0.6-2.1$ & 0.5 \\
\hline $\mathrm{TO} / \mathrm{B}$ & 11.0 & $4.7-17.1$ & 2.3 & 7.4 & $6.7-8.7$ & 0.6 & 4.7 & 3.8-6.5 & 0.8 \\
\hline
\end{tabular}

Numbers of progenies are 63, 42 and 48 for Kluang, UluPaka and TelukIntan, respectively;

$\mathrm{MFW}=$ mean fruit weight; MNW = mean nut weight; $\mathrm{M} / \mathrm{F}=$ mesocarp to fruit; $\mathrm{K} / \mathrm{F}=$ kernel to fruit; $\mathrm{S} / \mathrm{F}=$ shell to fruit; $\mathrm{O} / \mathrm{DM}=$ oil to dry mesocarp; O/WM = oil to wet mesocarp; $\mathrm{F} / \mathrm{B}=$ fruit to bunch; $\mathrm{O} / \mathrm{B}=$ oil to bunch; $\mathrm{K} / \mathrm{B}=$ kernel to bunch; $\mathrm{TO} / \mathrm{B}=$ total oil to bunch. 
Table 8 Mean squares, variance components and heritability estimates from NCM 1 analysis of the bunch components of fertile and parthenocarpic fruits (1986-1989) in trial 0.181, Kluang (planted 1982).

\begin{tabular}{|c|c|c|c|c|c|c|c|c|c|c|c|}
\hline Source & $\mathrm{df}$ & $\mathrm{M} / \mathrm{FF}$ & $\mathrm{K} / \mathrm{FF}$ & $\mathrm{S} / \mathrm{FF}$ & $\mathrm{O} / \mathrm{DMF}$ & $\mathrm{O} / \mathrm{WMF}$ & $\mathrm{O} / \mathrm{BF}$ & $\mathrm{M} / \mathrm{FP}$ & O/DMP & O/WMP & $\mathrm{O} / \mathrm{BP}$ \\
\hline Replications (R) & 2 & 88.10 & 3.90 & $110.63^{*}$ & 10.17 & 46.62 & 13.31 & 7.28 & $186.99^{*}$ & $443.07^{* *}$ & $82.53^{*}$ \\
\hline Pisiferas $(\mathrm{P})$ & 20 & $243.97^{* *}$ & 5.80 & $211.64^{* *}$ & $126.66^{* *}$ & $190.69^{* *}$ & $23.85^{*}$ & 12.42 & $179.08^{* *}$ & $214.58^{* *}$ & $38.70^{* *}$ \\
\hline $\begin{array}{l}\text { Oleiferas/Pisiferas } \\
(\mathrm{O} / \mathrm{P})\end{array}$ & 42 & $126.36^{* *}$ & 11.09 & $80.95^{* *}$ & 30.73 & 31.82 & 5.27 & 11.33 & 50.93 & 55.42 & 14.50 \\
\hline $\mathrm{P} \times \mathrm{R}$ & 40 & 47.65 & 6.49 & 32.84 & $32.13^{*}$ & 57.29 & $10.04^{*}$ & 11.05 & 67.47 & 88.51 & 19.79 \\
\hline $\mathrm{O} / \mathrm{P} \times \mathrm{R}$ & 84 & 55.89 & 7.03 & 39.30 & 28.83 & 47.13 & 3.63 & 8.06 & 60.97 & 81.07 & 20.77 \\
\hline Palms (W) & 305 & 42.37 & 7.07 & 30.26 & 18.50 & 40.97 & 5.35 & 10.80 & 36.26 & 61.80 & 16.73 \\
\hline Pooled error 1 (WP1) & 389 & 45.29 & 7.06 & 32.21 & 20.73 & 42.30 & 4.98 & 10.21 & 41.60 & 65.96 & 17.60 \\
\hline Pooled error 2 (WP2) & 429 & 45.51 & 7.01 & 32.27 & - & 43.70 & - & 10.29 & 44.01 & 68.06 & 17.81 \\
\hline$\sigma_{\mathrm{p}}^{2}$ & & $\begin{array}{l}7.46 \\
(10.45)\end{array}$ & $\begin{array}{l}0 \\
(0)\end{array}$ & $\begin{array}{l}8.15 \\
(15.71)\end{array}$ & $\begin{array}{l}5.49 \\
(17.01)\end{array}$ & $\begin{array}{l}8.82 \\
(15.37)\end{array}$ & $\begin{array}{l}0.72 \\
(10.13)\end{array}$ & $\begin{array}{l}0 \\
(0)\end{array}$ & $\begin{array}{l}7.21 \\
(11.15)\end{array}$ & $\begin{array}{l}9.00 \\
(10.23)\end{array}$ & $\begin{array}{l}1.49 \\
(6.99)\end{array}$ \\
\hline$\sigma_{\mathrm{o} / \mathrm{p}}^{2}$ & & $\begin{array}{l}11.70 \\
(16.39)\end{array}$ & $\begin{array}{l}0.68 \\
(8.84)\end{array}$ & $\begin{array}{l}6.93 \\
(13.36)\end{array}$ & $\begin{array}{l}0.32 \\
(0.99)\end{array}$ & $\begin{array}{l}0 \\
(0)\end{array}$ & $\begin{array}{l}0.27 \\
(3.80)\end{array}$ & $\begin{array}{l}0.54 \\
(4.75)\end{array}$ & $\begin{array}{l}0 \\
(0)\end{array}$ & $\begin{array}{l}0 \\
(0)\end{array}$ & $\begin{array}{l}0 \\
(0)\end{array}$ \\
\hline$\sigma_{\mathrm{pr}}^{2}$ & & $\begin{array}{l}0 \\
(0)\end{array}$ & $\begin{array}{l}0 \\
(0)\end{array}$ & (0) & $\begin{array}{l}0.59 \\
(1.83)\end{array}$ & $\begin{array}{l}1.81 \\
(3.15)\end{array}$ & $\begin{array}{l}1.14 \\
(16.03)\end{array}$ & $\begin{array}{l}0.53 \\
(4.66)\end{array}$ & $\begin{array}{l}1.16 \\
(1.79)\end{array}$ & $\begin{array}{l}1.32 \\
(1.50)\end{array}$ & 0 \\
\hline$\sigma_{(\mathrm{o} / \mathrm{p}) \mathrm{r}}^{2}$ & & $\begin{array}{l}6.73 \\
(9.43)\end{array}$ & $\begin{array}{l}0 \\
(0)\end{array}$ & $\begin{array}{l}4.51 \\
(8.70)\end{array}$ & $\begin{array}{l}5.15 \\
(15.95)\end{array}$ & $\begin{array}{l}3.07 \\
(5.35)\end{array}$ & $\begin{array}{l}0 \\
(0)\end{array}$ & $\begin{array}{l}0 \\
(0)\end{array}$ & $\begin{array}{l}12.30 \\
(19.02)\end{array}$ & $\begin{array}{l}9.59 \\
(10.90)\end{array}$ & $\begin{array}{l}2.01 \\
(9.43)\end{array}$ \\
\hline$h_{\mathrm{p}}^{2}$ & & 41.79 & 0 & 62.86 & 65.87 & 61.46 & 37.99 & 0 & 44.59 & 40.92 & 27.97 \\
\hline$h_{0}^{2}$ & & 65.55 & 35.38 & 53.45 & 3.84 & 0 & 14.25 & 19.01 & 0 & 0 & 0 \\
\hline$h_{0+p}^{2}$ & & 53.67 & 17.69 & 58.15 & 34.85 & 30.73 & 26.12 & 9.50 & 22.29 & 20.46 & 13.98 \\
\hline
\end{tabular}

df: degrees of freedom for the $F$-ratio on composite items; $\sigma^{2}$ : variance component estimated from the expectation of mean squares; $h^{2}$ : values of heritability based on intra-class correlations; * and ** mean values are significant at $P \leq 0.05$ and $P \leq 0.01$, respectively; -: the most likely estimate value is zero; values in parenthesis are the percentage of phenotypic variance of component; harmonic means for palms in female/rep (n') and $\mathrm{O} / \mathrm{P}\left(\mathrm{o}^{\prime}\right)=2.01$ and 2.80, respectively;

$\mathrm{M} / \mathrm{FF}=$ mesocarp to fruit (fertile fruits); K/FF = kernel to fruit (fertile fruits); $\mathrm{S} / \mathrm{FF}=$ shell to fruit (fertile fruits); $\mathrm{O} / \mathrm{DMF}=$ oil to dry mesocarp (fertile fruits); $\mathrm{O} / \mathrm{WMF}=$ oil to wet mesocarp (fertile fruits); $\mathrm{O} / \mathrm{BF}=$ oil to bunch (fertile fruits); $\mathrm{M} / \mathrm{FP}=$ mesocarp to fruit (parthenocarpic fruits); $\mathrm{O} / \mathrm{WMP}=$ oil to wet mesocarp (parthenocarpic fruits); $\mathrm{O} / \mathrm{BP}=$ oil to bunch (parthenocarpic fruits).

for $\mathrm{O} / \mathrm{DM}, \mathrm{O} / \mathrm{WM}$ and $\mathrm{O} / \mathrm{B}$. The parthenocarpic fruits showed no significant differences among $\mathrm{P}$ and $\mathrm{O}$-within-P for $\mathrm{O} / \mathrm{DM}$ and $\mathrm{O} / \mathrm{B}$. The parthenocarpic fruits showed low heritability based on $\mathrm{P}$ for $\mathrm{O} / \mathrm{DM}$ and O/B but intermediate for O/WM. However, based on O-within-P, the heritability estimates were low for O/DM, O/WM and O/B (Table 9).

For progeny data in Teluk Intan, there were significant differences among $\mathrm{P}$ and $\mathrm{O}$-within-P for $\mathrm{M} / \mathrm{F}$ and K/F. High heritability estimates were recorded when based on $\mathrm{P}$ for $\mathrm{M} / \mathrm{F}$ and $\mathrm{O}$-within-P for $\mathrm{K} / \mathrm{F}$. Significant differences among $\mathrm{P}$ were recorded for $\mathrm{O} / \mathrm{DM}, \mathrm{O} / \mathrm{WM}$ and $\mathrm{O} / \mathrm{B}$, but not for O-within-P. The heritability estimates obtained based on $\mathrm{P}$ were intermediate for O/DM, low for $\mathrm{O} / \mathrm{WM}$ and high for $\mathrm{O} / \mathrm{B}$. Heritability estimates based on O-within-P were intermediate for $\mathrm{O} / \mathrm{DMO} / \mathrm{WM}$ and $\mathrm{O} / \mathrm{B}$. For parthenocarpic fruits, there were significant differences among $\mathrm{P}$ and O-within-P for O/DM, $\mathrm{O} / \mathrm{WM}$ and $\mathrm{O} / \mathrm{B}$. The heritability estimates based on $\mathrm{P}$ were intermediate for $\mathrm{O} / \mathrm{DM}$ and high for $\mathrm{O} / \mathrm{WM}$ and $\mathrm{O} / \mathrm{B}$. The heritability estimate based on O-within-P, were intermediate for $\mathrm{O} / \mathrm{DM}$ and $\mathrm{O} / \mathrm{B}$ but high for O/WM (Table 10).

\subsection{Vegetative Traits}

The palms were vegetatively most vigorous in Ulu Paka, followed by Teluk Intan and Kluang. This was observed in the highest value for petiole cross-section (PCS), rachis length (RL), leaflet length (LL), leaflet number (LN), height (HT) and leaflet area (LA) for palms in Ulu Paka. Palms in Kluang however were measured with the lowest height and height increment rate (HTI) among the three locations (Table 11).

Palms in Kluang showed significant differences among $\mathrm{P}$ and O-within-P for PCS and RL. For HT, 

and Vegetative Traits in Oil Palm Interspecific Hybrids

Table 9 Mean squares, variance components and heritability estimates from NCM 1 analysis of bunch components of fertile and parthenocarpic fruits (1987-1993) in trial 0.196, Ulu Paka (planted in 1984).

\begin{tabular}{lllllllllll}
\hline Source & $\mathrm{df}$ & $\mathrm{M} / \mathrm{FF}$ & $\mathrm{K} / \mathrm{FF}$ & $\mathrm{S} / \mathrm{FF}$ & $\mathrm{O} / \mathrm{DMF}$ & $\mathrm{O} / \mathrm{WMF}$ & $\mathrm{O} / \mathrm{BF}$ & $\mathrm{O} / \mathrm{DMP}$ & $\mathrm{O} / \mathrm{WMP}$ & $\mathrm{O} / \mathrm{BP}$ \\
\hline Replications (R) & 7 & $98.64^{*}$ & 6.88 & $74.65^{*}$ & $120.92^{*}$ & 134.58 & 2.31 & 180.13 & 196.11 & 5.10 \\
Pisiferas (P) & 11 & $156.80^{* *}$ & $23.66^{* *}$ & $80.99^{* *}$ & 61.29 & $341.40^{* *}$ & 4.03 & 170.60 & $416.01^{* *}$ & 8.94 \\
Oleiferas/Pisiferas & 29 & $97.57^{* *}$ & $12.38^{*}$ & $60.32^{*}$ & 55.42 & 94.17 & 5.68 & 85.43 & 107.30 & 6.06 \\
(O/P) & 77 & 47.78 & 7.10 & 28.66 & 43.69 & 85.94 & 4.94 & 96.26 & 91.08 & 5.48 \\
$\mathrm{P} \times \mathrm{R}$ & 203 & 42.22 & 5.60 & 28.27 & 36.54 & 70.51 & 3.69 & 93.25 & 96.06 & 5.53 \\
$\mathrm{O} / \mathrm{P} \times \mathrm{R}$ & 228 & 45.21 & 7.44 & 29.12 & 53.59 & 91.43 & 3.43 & 115.68 & 101.32 & 5.03 \\
Palms (W) & 431 & 43.80 & 6.57 & 28.72 & 45.56 & 81.58 & 3.55 & 105.11 & 98.84 & 5.26 \\
Pooled error 1 (WP1) & 508 & 44.41 & 6.65 & 28.71 & 45.28 & 82.24 & 3.76 & 103.77 & 97.67 & 5.30 \\
Pooled error 2 (WP2) & & 1.50 & 0.27 & 0.57 & 0 & 6.46 & 0 & 2.29 & 8.75 & 0.08 \\
\hline$\sigma_{\mathrm{p}}^{2}$ & & $(2.88)$ & $(3.43)$ & $(1.77)$ & $(0)$ & $(6.85)$ & $(0)$ & $(2.15)$ & $(8.14)$ & $(1.38)$ \\
$\sigma^{2}{ }_{\mathrm{o} / \mathrm{p}}$ & & 4.96 & 0.61 & 2.87 & 1.69 & 2.12 & 0.18 & 0 & 1.01 & 0.05 \\
$\sigma_{\mathrm{pr}}^{2}$ & & $(9.52)$ & $(7.75)$ & $(8.90)$ & $(3.48)$ & $(2.25)$ & $(4.08)$ & $(0)$ & $(0.94)$ & $(0.86)$ \\
$\sigma_{(\mathrm{o} / \mathrm{p}) \mathrm{r}}$ & & $(1.24$ & 0.34 & 0.09 & 1.60 & 3.44 & 0.28 & 0.67 & 0 & 0 \\
$\mathrm{~h}_{\mathrm{p}}^{2}$ & & 0 & 0 & 0 & 0 & 0 & 0.19 & 0 & 0 & $(0.38)$ \\
$h^{2}$ & & $(4.32)$ & $(0.28)$ & $(3.29)$ & $(3.65)$ & $(6.35)$ & $(0.63)$ & $(0)$ & $(0)$ \\
$h^{2}{ }_{\mathrm{o}+\mathrm{p}}$ & & $(0)$ & $(0)$ & $(0)$ & $(0)$ & $(0)$ & $(4.31)$ & $(0)$ & $(0)$ & $(6.22)$ \\
\hline
\end{tabular}

df: degrees of freedom for the F-ratio on composite items; $\sigma^{2}$ : variance component estimated from the expectation of mean squares; $h^{2}$ : values of heritability based on intra-class correlations; * and ** mean values are significant at $P \leq 0.05$ and $P \leq 0.01$, respectively; -: the most likely estimate value is zero; values in parenthesis are the percentage of phenotypic variance of component; harmonic means for palms in female/rep (n') and $\mathrm{O} / \mathrm{P}\left(\mathrm{o}^{\prime}\right)=1.39$ and 3.21, respectively;

$\mathrm{M} / \mathrm{FF}=$ mesocarp to fruit (fertile fruits); K/FF = kernel to fruit (fertile fruits); $\mathrm{S} / \mathrm{FF}=$ shell to fruit (fertile fruits); $\mathrm{O} / \mathrm{DMF}=$ oil to dry mesocarp (fertile fruits); $\mathrm{O} / \mathrm{WMF}=$ oil to wet mesocarp (fertile fruits); $\mathrm{O} / \mathrm{BF}=$ oil to bunch (fertile fruits); M/FP = mesocarp to fruit (parthenocarpic fruits); $\mathrm{O} / \mathrm{WMP}=$ oil to wet mesocarp (parthenocarpic fruits); $\mathrm{O} / \mathrm{BP}=$ oil to bunch (parthenocarpic fruits).

Table 10 Mean squares, variance components and heritability estimates from NCM 1 analysis of bunch components of fertile and parthenocarpic fruits (1988-1992) in trial 0.821, Teluk Intan (planted in 1981).

\begin{tabular}{lllllllllll}
\hline Source & $\mathrm{df}$ & $\mathrm{M} / \mathrm{FF}$ & $\mathrm{K} / \mathrm{FF}$ & $\mathrm{S} / \mathrm{FF}$ & $\mathrm{O} / \mathrm{DMF}$ & $\mathrm{O} / \mathrm{WMF}$ & $\mathrm{O} / \mathrm{BF}$ & $\mathrm{O} / \mathrm{DMP}$ & $\mathrm{O} / \mathrm{WMP}$ & $\mathrm{O} / \mathrm{BP}$ \\
\hline Replications (R) & 1 & 113.47 & 0.04 & $117.82^{*}$ & 27.50 & 0.61 & 5.10 & 49.51 & 91.32 & $1.05^{*}$ \\
Pisiferas (P) & 18 & $244.67^{* *}$ & $20.11^{* *}$ & $175.27^{* *}$ & $53.02^{* *}$ & $65.40^{* *}$ & $13.49^{* *}$ & $146.96^{* *}$ & $335.82^{* *}$ & $1.09^{* *}$ \\
Oleiferas/Pisiferas (O/P) & 29 & $69.29^{*}$ & $13.22^{* *}$ & 29.45 & 21.04 & 36.68 & 4.10 & $72.82^{*}$ & $120.59^{*}$ & $0.45^{*}$ \\
$\mathrm{P} \times \mathrm{R}$ & 18 & 37.77 & 5.10 & 26.05 & 18.95 & 26.30 & 3.77 & 37.38 & 58.03 & 0.24 \\
$\mathrm{O} / \mathrm{P} \times \mathrm{R}$ & 29 & 22.04 & 4.07 & 15.01 & 13.38 & 18.01 & 3.49 & 51.01 & 53.92 & 0.26 \\
Palms (W) & 254 & 33.96 & 4.66 & 22.40 & 14.81 & 27.52 & 2.92 & 42.32 & 63.23 & 0.21 \\
Pooled error 1 (WP1) & 283 & 32.74 & 4.60 & 21.64 & 14.66 & 26.55 & 2.98 & 43.21 & 62.28 & 0.21 \\
Pooled error 2 (WP2) & 301 & 33.04 & 4.63 & 21.91 & 14.92 & 26.53 & 3.02 & 42.86 & 62.02 & 0.22 \\
\hline$\sigma_{\mathrm{p}}^{2}$ & & 10.62 & 0.39 & 0.97 & 1.76 & 1.36 & 0.61 & 5.84 & 14.04 & 0.04 \\
$\sigma_{\mathrm{o} / \mathrm{p}}^{2}$ & & $(19.96)$ & $(5.90)$ & $(3.64)$ & $(9.45)$ & $(4.26)$ & $(15.44)$ & $(10.64)$ & $(16.11)$ & $(13.05)$ \\
$\sigma_{\mathrm{pr}}^{2}$ & & 7.46 & 1.45 & 2.28 & 1.21 & 2.95 & 0.10 & 3.45 & 10.53 & 0.03 \\
$h^{2}$ & & $(14.02)$ & $(21.94)$ & $(8.56)$ & $(6.49)$ & $(9.24)$ & $(2.53)$ & $(6.28)$ & $(12.08)$ & $(9.78)$ \\
$h^{2}$ & & 2.09 & 0.14 & 1.47 & 0.74 & 1.10 & 0.04 & 0 & 0.55 & 0 \\
$h^{2}{ }_{\mathrm{o}+\mathrm{p}}$ & & $79.93)$ & $(2.12)$ & $(5.52)$ & $(3.97)$ & $(3.44)$ & $(1.01)$ & $(0)$ & $(0.63)$ & $(0)$ \\
\hline
\end{tabular}

df: degrees of freedom for the $F$-ratio on composite items; $\sigma^{2}$ : variance component estimated from the expectation of mean squares; $h^{2}$ : values of heritability based on intra-class correlations; * and ** mean values are significant at $P \leq 0.05$ and $P \leq 0.01$, respectively; -: the most likely estimate value is zero; values in parenthesis are the percentage of phenotypic variance of component; harmonic means for palms in female/rep (n') and $\mathrm{O} / \mathrm{P}\left(\mathrm{o}^{\prime}\right)=3.16$ and 2.38, respectively;

$\mathrm{M} / \mathrm{FF}=$ mesocarp to fruit (fertile fruits); $\mathrm{K} / \mathrm{FF}=$ kernel to fruit (fertile fruits); $\mathrm{S} / \mathrm{FF}=$ shell to fruit (fertile fruits); $\mathrm{O} / \mathrm{DMF}=$ oil to dry mesocarp (fertile fruits); $\mathrm{O} / \mathrm{WMF}=$ oil to wet mesocarp (fertile fruits); $\mathrm{O} / \mathrm{BF}=$ oil to bunch (fertile fruits); $\mathrm{M} / \mathrm{FP}=$ mesocarp to fruit (parthenocarpic fruits); $\mathrm{O} / \mathrm{WMP}=$ oil to wet mesocarp (parthenocarpic fruits); $\mathrm{O} / \mathrm{BP}=$ oil to bunch (parthenocarpic fruits). 

and Vegetative Traits in Oil Palm Interspecific Hybrids

Table 11 Means, ranges and least significant differences for vegetative traits measured on $\mathbf{O} \times \mathbf{P}$ progenies planted in three locations.

\begin{tabular}{|c|c|c|c|c|c|c|c|c|c|}
\hline \multirow{2}{*}{ Trait } & \multicolumn{3}{|c|}{ Kluang } & \multicolumn{3}{|c|}{ Ulu Paka } & \multicolumn{3}{|c|}{ Teluk Intan } \\
\hline & Mean & Range & LSD & Mean & Range & LSD & Mean & Range & LSD \\
\hline PCS $\left(\mathrm{cm}^{2}\right)$ & 22.4 & $8.7-34.0$ & 11.5 & 38.3 & $32.8-42.9$ & 3.1 & 32.7 & $26.9-45.5$ & 4.3 \\
\hline RL (m) & 4.9 & $3.9-5.8$ & 1.0 & 6.0 & $5.8-6.3$ & 0.2 & 5.7 & $5.1-6.2$ & 0.3 \\
\hline LL (cm) & 95.3 & 78.5-116.9 & 15.8 & 112.4 & $96.5-131.0$ & 5.2 & 110.0 & $96.7-122.5$ & 8.6 \\
\hline $\mathrm{LW}(\mathrm{cm})$ & 5.4 & 3.8-6.9 & 1.2 & 6.8 & $6.1-7.4$ & 0.3 & 6.9 & $5.8-7.6$ & 0.6 \\
\hline LN (no.) & 138.0 & $111-159$ & 21.9 & 156.0 & $145-162$ & 5.6 & 147.0 & $133-159$ & 7.5 \\
\hline $\mathrm{HT}(\mathrm{cm})$ & 54.0 & $28.0-88.0$ & 0.3 & 165.0 & $133-208$ & 0.1 & 125.0 & $94.0-159.0$ & 0.4 \\
\hline HTI (cm/year)* & 14.0 & $7.0-22.0$ & 0.0 & 24.0 & $19.0-30.0$ & 0.0 & 25.0 & $19.0-32.0$ & 0.0 \\
\hline $\mathrm{LA}\left(\mathrm{cm}^{2}\right)$ & 8.1 & $5.4-12.9$ & 3.1 & 13.5 & $11.2-16.2$ & 1.0 & 12.7 & $10.2-15.7$ & 1.6 \\
\hline
\end{tabular}

* HTI $=$ (height at year $t) /(t-2)$, according to Breure and Powell [26], where $\mathrm{t}=6,9$ and 7 for Kluang, UluPaka and TelukIntan, respectively.

Numbers of progenies are 73, 42 and 48 for Kluang, UluPaka and TelukIntan, respectively.

PCS = petiole cross-section; $\mathrm{RL}=$ rachis length; $\mathrm{LL}=$ leaflet length; $\mathrm{LW}=$ leaflet width; $\mathrm{LN}=$ leaflet number; HT = height; HTI = height increment; LA = leaflet area.

Table 12 Mean squares, variance components and heritability estimates from NCM 1 analysis for vegetative traits (1988) in trial 0.181, Kluang (planted in 1982).

\begin{tabular}{|c|c|c|c|c|}
\hline Source & df & PCS & RL & HT \\
\hline Replications (R) & 2 & $788.48^{* *}$ & $4.57^{* *}$ & $1.94^{* *}$ \\
\hline Pisiferas (P) & 20 & $232.71^{* *}$ & $1.92^{* *}$ & $0.05^{* *}$ \\
\hline Oleiferas/Pisiferas $(\mathrm{O} / \mathrm{P})$ & 51 & $63.45^{* *}$ & $0.67^{* *}$ & 0.02 \\
\hline $\mathrm{P} \times \mathrm{R}$ & 40 & 31.64 & 0.31 & 0.02 \\
\hline $\mathrm{O} / \mathrm{P} \times \mathrm{R}$ & 102 & 29.51 & 0.22 & 0.02 \\
\hline Palms (W) & & $\begin{array}{l}26.99 \\
(877)\end{array}$ & $\begin{array}{l}0.28 \\
(877)\end{array}$ & $\begin{array}{l}0.02 \\
(868)\end{array}$ \\
\hline Pooled error 1 (WP1) & & $\begin{array}{l}27.26 \\
(979)\end{array}$ & $\begin{array}{l}0.28 \\
(979)\end{array}$ & $\begin{array}{l}0.02 \\
(970)\end{array}$ \\
\hline Pooled error 2 (WP2) & & $\begin{array}{l}27.43 \\
(1019)\end{array}$ & $\begin{array}{l}0.28 \\
(1019)\end{array}$ & $\begin{array}{l}0.02 \\
(1010)\end{array}$ \\
\hline$\sigma_{p}^{2}$ & & $\begin{array}{l}3.50 \\
(10.35)\end{array}$ & $\begin{array}{l}0.02 \\
(7.36)\end{array}$ & $\begin{array}{l}0.001 \\
(2.67)\end{array}$ \\
\hline$\sigma_{\mathrm{o} / \mathrm{p}}^{2}$ & & $\begin{array}{l}2.26 \\
(6.69)\end{array}$ & $\begin{array}{l}0.03 \\
(8.74)\end{array}$ & $\begin{array}{l}0.001 \\
(2.23)\end{array}$ \\
\hline$\sigma_{\mathrm{pr}}^{2}$ & & $\begin{array}{l}0.13 \\
(0.40)\end{array}$ & $\begin{array}{l}0.01 \\
(1.61)\end{array}$ & $\begin{array}{l}0 \\
(0)\end{array}$ \\
\hline$\sigma_{(\mathrm{o} / \mathrm{p}) \mathrm{r}}^{2}$ & & $\begin{array}{l}0.50 \\
(1.49)\end{array}$ & $\begin{array}{l}0 \\
(0)\end{array}$ & $\begin{array}{l}0.0001 \\
(0.44)\end{array}$ \\
\hline$\sigma_{w}^{2}$ & & - & - & - \\
\hline$\sigma_{\text {wp1 }}^{2}$ & & - & - & - \\
\hline$\sigma_{\text {wp2 }}^{2}$ & & $\begin{array}{l}27.43 \\
(81.07)\end{array}$ & $\begin{array}{l}0.28 \\
(82.28)\end{array}$ & $\begin{array}{l}0.02 \\
(94.83)\end{array}$ \\
\hline$h_{\mathrm{p}}^{2}$ & & 41.4 & 29.5 & 10.7 \\
\hline$h^{2}{ }_{0}$ & & 26.8 & 35.0 & 8.9 \\
\hline$h^{2}{ }_{0+p}$ & & 34.1 & 32.2 & 9.8 \\
\hline
\end{tabular}

df: degrees of freedom for the $F$-ratio on composite items; $\sigma^{2}$ : variance component estimated from the expectation of mean squares; $h^{2}$ : values of heritability based on intra-class correlations; * and ** mean values are significant at $P \leq 0.05$ and $P \leq 0.01$, respectively; -: the most likely estimate value is zero; values in parenthesis are the percentage of phenotypic variance of component; harmony means for palms in female/rep (n') and $\mathrm{O} / \mathrm{P}\left(\mathrm{o}^{\prime}\right)=5.00$ and 3.18, respectively;

$\mathrm{PCS}=$ petiole cross section; $\mathrm{RL}=$ rachis length; $\mathrm{HT}=$ height. 

and Vegetative Traits in Oil Palm Interspecific Hybrids

Table 13 Mean squares, variance components and heritability estimates from NCM 1 analysis for vegetative traits (1993) in trial 0.196, Ulu Paka (planted in 1984).

\begin{tabular}{|c|c|c|c|c|}
\hline Source & $\mathrm{df}$ & PCS & RL & HT \\
\hline Replications (R) & 6 & $868.91^{* *}$ & $2.95^{* *}$ & $3.6227^{* *}$ \\
\hline Pisiferas (P) & 11 & $457.54^{* *}$ & $0.61^{* *}$ & $6.6529^{* *}$ \\
\hline Oleiferas/Pisiferas (O/P) & 30 & $179.12^{* *}$ & $0.62^{* *}$ & $0.7240^{* * *}$ \\
\hline $\mathrm{P} \times \mathrm{R}$ & 66 & 50.30 & 0.20 & 0.0845 \\
\hline $\mathrm{O} / \mathrm{P} \times \mathrm{R}$ & 180 & 43.09 & 0.19 & 0.0766 \\
\hline Palms (W) & 1,235 & 42.46 & 0.12 & 0.0745 \\
\hline Pooled error 1 (WP1) & 1,415 & 42.54 & 0.13 & 0.0748 \\
\hline Pooled error 2 (WP2) & 1,481 & 42.88 & 0.13 & 0.0752 \\
\hline 20 & & $\begin{array}{l}2.52 \\
(5.05)\end{array}$ & $\begin{array}{l}0 \\
(0)\end{array}$ & $\begin{array}{l}0.0168 \\
(15.07)\end{array}$ \\
\hline$\sigma_{\mathrm{o} / \mathrm{p}}^{2}$ & & $\begin{array}{l}3.90 \\
(782)\end{array}$ & 0.01 & $\begin{array}{l}0.0186 \\
(1668)\end{array}$ \\
\hline & & 0.44 & 0 & 0.0005 \\
\hline$\sigma_{\mathrm{pr}}^{2}$ & & $(0.88)$ & $(0)$ & $(0.4)$ \\
\hline$\sigma_{(0 / p) r}^{2}$ & & 0.13 & 0 & 0.0004 \\
\hline & & $(0.26)$ & (0) & $(0.4)$ \\
\hline$\sigma_{\mathrm{w}}$ & & - & - & - \\
\hline$\sigma_{\mathrm{wp} 1}^{2}$ & & - & - & - \\
\hline$\sigma_{\text {wp2 }}^{2}$ & & $\begin{array}{l}42.88 \\
(85.98)\end{array}$ & $\begin{array}{l}0.13 \\
(92.86)\end{array}$ & $\begin{array}{l}0.0752 \\
(67.44)\end{array}$ \\
\hline$h_{\mathrm{p}}^{2}$ & & 20.2 & 0 & 60.3 \\
\hline$h^{2}{ }_{0}^{p}$ & & 31.3 & 28.6 & 66.7 \\
\hline$h_{0+p}^{2}$ & & 25.8 & 14.3 & 63.5 \\
\hline
\end{tabular}

df: degrees of freedom for the $F$-ratio on composite items; $\sigma^{2}$ : variance component estimated from the expectation of mean squares; $h^{2}$ : values of heritability based on intra-class correlations; * and ** mean values are significant at $P \leq 0.05$ and $P \leq 0.01$, respectively; -: the most likely estimate value is zero; values in parenthesis are the percentage of phenotypic variance of component; harmony means for palms in female/replication (n') and $\mathrm{O} / \mathrm{P}\left(\mathrm{o}^{\prime}\right)=5.00$ and 3.18, respectively;

$\mathrm{PCS}=$ petiole cross section; $\mathrm{RL}=$ rachis length; $\mathrm{HT}=$ height.

Table 14 Mean squares, variance components and heritability estimates from NCM 1 analysis for vegetative traits (1988) in trial 0.821, TelukIntan (planted in 1981).

\begin{tabular}{|c|c|c|c|c|}
\hline Source & $\mathrm{df}$ & PCS & RL & HT \\
\hline Replications (R) & 1 & 14.94 & 0.14 & 0.06 \\
\hline Pisiferas $(\mathrm{P})$ & 18 & $231.85^{* *}$ & $0.92^{* *}$ & $0.26^{* *}$ \\
\hline Oleiferas/Pisiferas $(\mathrm{O} / \mathrm{P})$ & 29 & $63.87^{* *}$ & 0.21 & $0.08^{* *}$ \\
\hline $\mathrm{P} \times \mathrm{R}$ & 18 & 38.11 & 0.14 & 0.02 \\
\hline $\mathrm{O} / \mathrm{P} \times \mathrm{R}$ & 29 & 25.37 & 0.17 & 0.03 \\
\hline Palms (W) & 373 & 22.91 & 0.12 & 0.03 \\
\hline Pooled error 1 (WP1) & 402 & 23.09 & 0.12 & 0.03 \\
\hline Pooled error 2 (WP2) & 420 & 23.73 & 0.12 & 0.03 \\
\hline$\sigma_{\mathrm{p}}^{2}$ & & $\begin{array}{l}6.73 \\
(18.67)\end{array}$ & $\begin{array}{l}0.03 \\
(10.78)\end{array}$ & $\begin{array}{l}0.01 \\
(20.16)\end{array}$ \\
\hline$\sigma_{\mathrm{o} / \mathrm{p}}^{2}$ & & 3.97 & 0.004 & $\begin{array}{l}0.01 \\
(2016)\end{array}$ \\
\hline & & $\begin{array}{l}(11.01) \\
1.11\end{array}$ & $\begin{array}{l}(1.44) \\
0\end{array}$ & $\begin{array}{l}(20.16) \\
0\end{array}$ \\
\hline$\sigma_{\mathrm{pr}}$ & & $(3.08)$ & (0) & $(0)$ \\
\hline$\sigma_{(o / p) r}^{2}$ & & $\begin{array}{l}0.51 \\
(1.41)\end{array}$ & 0.12 & 0 \\
\hline$\sigma_{\mathrm{w}}^{2}$ & & $\begin{array}{l}(1.41) \\
-\end{array}$ & $\begin{array}{l}(43.12) \\
-\end{array}$ & $\begin{array}{l}(0) \\
-\end{array}$ \\
\hline$\sigma_{\text {wp } 1}^{2}$ & & - & - & - \\
\hline$\sigma_{\mathrm{wp} 2}^{2}$ & & $\begin{array}{l}23.73 \\
(65.82)\end{array}$ & $\begin{array}{l}0.12 \\
(44.66)\end{array}$ & $\begin{array}{l}0.03 \\
(59.68)\end{array}$ \\
\hline$h_{\mathrm{p}}^{2}$ & & 74.7 & 43.1 & 80.6 \\
\hline$h_{0}^{2}$ & & 44.1 & 5.8 & 80.6 \\
\hline$h_{0+p}^{2}$ & & 59.4 & 24.4 & 80.6 \\
\hline
\end{tabular}



and Vegetative Traits in Oil Palm Interspecific Hybrids

significant differences were observed among $\mathrm{P}$ but not among O-within-P. The heritability estimates based on both P and O-within-P were intermediate for PCS and RL but low for HT (Table 12).

For palms in Ulu Paka, there were significant differences among both $\mathrm{P}$ and O-within-P for PCS, RL and HT. The heritability estimates based on both $\mathrm{P}$ and O-within-P were intermediate for PCS, low for RL and high for HT (Table 13).

There were significant differences among P for PCS, RL and HT and among O-within-P for PCS and HT in Teluk Intan. The heritability estimates based on both $\mathrm{P}$ and O-within-P were intermediate for RL but high for PCS and HT (Table 14).

\section{Conclusions}

The FFB yield of interspecific hybrids appeared to perform better on coastal (Teluk Intan and Carey Island) than inland (Kluang and Ulu Paka) soils. There appeared to be a two-fold difference in $\mathrm{BN}$, among hybrids in coastal soils compared to inland soils. With regards to the bunch components, $\mathrm{F} / \mathrm{B}$ and $\mathrm{O} / \mathrm{B}$ of the parthenocarpic fruits were found to be very important in determining the $\mathrm{O} / \mathrm{B}$ of the hybrids. The $\mathrm{O} / \mathrm{B}$ was the highest in Kluang, followed by UluPaka and Teluk Intan.

For immediate exploitation, cloning of outstanding individual palms via tissue culture could be pursued. For long term breeding programme, the backcrossing of interspecific hybrids to $E$. guineensis could also be pursued to introgress traits of interest from E. oleifera and E. guineensis. Eventually, highly homozygous individuals could be selected for commercial planting.

\section{Acknowledgments}

The authors thank the Director of General of MPOB for permission to publish this paper.

\section{References}

[1] Beirnaert, A., and Vanderweyen, R. 1941. "Contribution to Genetic and Biometric Study of Elaeis guineensis Jacq. Varieties.” Publ. INEAC Ser. Sci. 27: 101. (in French)
[2] Hardon, J. J., and Tan, G. Y. 1969. "Interspecific Hybrids in the Genus Elaeis: Part I, Crossability, Cytogenetics and Fertility of the F1 Hybrids of E. guineensis $\times E$. oleifera.” Euphytica 18 (3): 372-9.

[3] Obasola, C. O. 1973. "Breeding for Short-Stemmed Oil Palm in Nigeria.” J. Nig. Inst. Oil Res. 5 (18): 43.

[4] Meunier, J., and Boutin, D. 1975. "Elaeis melanococca and E. melanococca $\times$ E. guineensis Hybrid.” Oleagineux 30: 5-8. (in French)

[5] Tam, T. K., Lim, C. S., Yeoh, G. H., and Ooi, S. C. 1977. "The Oil Palm and Other Characteristics of Interspecific (Elaeis guineensis $\times$ E. oleifera) Hybrids Planted in Malaysia and Their Significance for Future Breeding Programmes.” In International Developments in Oil Palm, edited by Earp, D. A., and Newall, W. Kuala Lumpur: Incorporated Society of Planters, 27-38.

[6] Hardon, J. J. 1969. "Interspecific Hybrids in the Genus Elaeis: Part II, Vegetative Growth and Yield of F1 Hybrids E. guineensis $\times$ E. oleifera." Euphytica 18 (3): 380-8.

[7] Macfarlane, N., Swetman, T., and Cornelius, J. A. 1975. "Analysis of Mesocarp and Kernel Oils from the American Oil Palm and F1 Hybrids with the West African Oil Palm.” J. Sci. Food Agric. 26 (9): 1293-8.

[8] Arnaud, F., and Rabechault, H. 1972. "First Observations on the Cystohistochemical Characters of the Resistance of Oil Palm to 'Sudden Wilting'," Oleagineux 27 (11): 525-9. (in French)

[9] British Library. 1974. Replanting Diseased Oil Palm Areas with Elaeis oleifera $\times$ E. guineensis Hybrids at 'La Arenosa' Estate in Colombia.” Oil Palm News 18: 1-6.

[10] Meunier, J. 1987. "Prospects of E. oleifera $\times E$. guineensis Interspecific Hybrids-IRHO Results.” In Proceeding of ISOPB/PORIM Workshop on Prospects of Interspecific Hybrid, 11-5.

[11] Meunier, J., and Hardon, J. J. 1976. "Interspecific Hybrids between Elaeis guineensis and Elaeis oleifera." In Oil Palm Research, edited by Corley, R. H. V., Hardon, J. J., and Wood, B. J. Amsterdam: Elsevier, 127-38.

[12] Meunier, J., Vallejo, G., and Boutin, D. 1976. “E. melanococca $\times$ E. guineensis Hybrid and Its Improvement: A New Future for the Oil Palm.” Oleagineux 31: 519-28.

[13] Rajanaidu, N. 1985. "Elaeis oleifera Collection in Central and South America." In Proceedings of International Workshop on Oil Palm Germplasm and Utilization, 84.

[14] Rajanaidu, N., Rao, V., and Kushairi, A. 1989. "Genetic Analysis of Yield, Vegetative Growth and Fatty Acid Composition (FAC) in Interspecific (Elaeis oleifera $\times E$. guineensis) Hybrids." In Proceeding of ISOPB/PORIM Workshop on Prospects of Interspecific Hybrids, 28-39.

[15] Mukesh, S., and Tan, Y. P. 1989. "Performance of the 

and Vegetative Traits in Oil Palm Interspecific Hybrids

Elaeis oleifera $\times$ E. guineensis $(\mathrm{O} \times \mathrm{G})$ Hybrids and Their Backcrosses.” In Proceeding of 1989 PORIM International Palm Oil Congress, 40-3.

[16] Romero, H., Prada, F., Arias, D., Moreno, L., Rivera, Y., Daza, E., Avila, R., and Forero, D. 2013. "Performance of the Oil Palm Interspecific Elaeis oleifera $\times$ Elaeis guineensis $(\mathrm{O} \times \mathrm{G})$ Hybrids.” In Proceeding of International Seminar on Oil Palm Breed, 82-91.

[17] De Franqueville, H. 2003. "Oil Palm Bud Rot in Latin America.” Expl. Agric. 39 (3): 225-40.

[18] Martinez, G., Arango, M., Torres, G., Saria, G., Velez, D., Rodriguez, J., Mestizo, Y., Aya, H., Norena, C., Varon, F., Drenth, A., and Guest, D. 2011. "Advances in the Research of the Two Most Important Diseases on Oil Palm in Colombia: Bud Rot and Lethal Wilt.” In Proceeding of 2011 International Palm Oil Congress -Agriculture, Biotechnology and Sustainability Conference, 473-80.

[19] Comstock, R. E., and Robinson, H. F. 1952. "Estimation of Average Dominance of Genes.” In Heterosis, edited by Gowen, J. W. Ames, Iowa: Iowa State University Press, 494-516.

[20] Mohd-Din, A. 2000. "Genetic Variation for Yield, Bunch Components and Vegetative Traits in Oil Palm (Elaeis oleifera) and Interspecific Hybrids.” Ph.D. thesis,
Universiti Kebangsaan Malaysia, Bangi.

[21] Blaak, G., Sparnaaij, L. D., and Menendez, T. 1963. "Breeding and Inheritance in the Oil Palm (Elaeis guineensis Jacq.): Part II, Methods of Bunch Quality Analysis.” J. W. Afr. Inst. Oil Palm Res. 4: 146-55.

[22] Rao, V., Soh, A. C., Corley, R. H. V., Lee, C. H., Rajanaidu, N., Tan, Y. P., Chin, C. W., Lim, K. C., Tan, S. T., Lee, T. P., and Ngui, M. 1983. "A Critical Reexamination of the Method of Bunch Quality Analysis in Oil Palm Breeding.” PORIM Occasional Paper 9: $1-28$.

[23] Corley, R. H. V., and Breure, C. J. 1981. Measurements in Oil Palm Experiments. Internal Report, Unipamol Malaysia Sdn. Bhd. and Harrisons Fleming Advisory Service.

[24] Lawrence, M. J. 1984. "The Genetical Analysis of Ecological Traits.” In Evolutionary Ecology. Blackwell, Oxford: British Ecological Society, 27-63.

[25] Falconer, D. S. 1981. Introduction to Quantitative Genetics, 2nd ed.. London, New York: Longmans Green Publisher, 148-69.

[26] Breure, C. J., and Powell, M. S. 1988. "The One-Shot Method of Establishing Growth Parameters in Oil Palm.” In Proceeding of 1987 International Oil Palm/Palm Oil Conference, 203-9. 